\title{
Assessment of Satisfaction with Life among Elderly Patients Receiving HIV Care and Treatment in Mulago HIV Clinic: A Chronic Illness Quality of Life Model
}

\author{
Francis Kalule $^{1 *}$, Alimah Komuhangi², Micheal Buwembo ${ }^{3}$, Thomas Katairo ${ }^{4}$, Martha Tusabe $^{5}$ \\ ${ }^{1}$ Institute of Public Health and Management, Clarke International University, Kampala, Uganda \\ ${ }^{2}$ Clarke International University, Kampala, Uganda \\ ${ }^{3}$ Reach Out Mbuya Parish HIV/AIDS Initiative, Kampala, Uganda \\ ${ }^{4}$ Infectious Disease Research Collaboration, Kampala, Uganda \\ ${ }^{5}$ Ernest Cook Ultrasound Research and Education Institute, Kampala, Uganda \\ Email: ^franciskalule2@gmail.com
}

How to cite this paper: Kalule, F., Komuhangi, A., Buwembo, M., Katairo, T. and Tusabe, M. (2021) Assessment of Satisfaction with Life among Elderly Patients Receiving HIV Care and Treatment in Mulago HIV Clinic: A Chronic Illness Quality of Life Model. World Journal of AIDS, 11, 152180.

https://doi.org/10.4236/wja.2021.114012

Received: November 4, 2021

Accepted: December 18, 2021

Published: December 21, 2021

Copyright $\odot 2021$ by author(s) and Scientific Research Publishing Inc. This work is licensed under the Creative Commons Attribution International License (CC BY 4.0)

http://creativecommons.org/licenses/by/4.0/ (c) (i) Open Access

\begin{abstract}
Objective: This study aimed at assessing satisfaction with life among elderly HIV patients attending Mulago HIV Clinic. Methodology: A cross-sectional study design carried out among elderly people ( $>50$ years old) attending $\mathrm{Mu}$ lago HIV clinic, as stated by the WHO standard age cut-off of $>50$ years. A random selection of 353 elderly HIV patients was made. The study collected quantitative data to assess patient satisfaction with life, Illness related to discrimination, Barriers to healthcare and social services, and Physical wellbeing, social support and coping using quantitative data collection techniques. Interview discussions were harnessed to obtain patients' opinions and perceptions and then results grouped into themes. EPIDATA and STATA 14.2 statistical softwares were used for statistical analysis. Results: The study showed that only variables that were significantly associated at multivariate level are, disagreeing that other patients are seen before you when you are first to arrive, which had an odds ratio of 2.87 , disagreeing that your employer can never promote you which had an odds ratio of 6.87 compared to agreeing, not being sure whether friend or family member cannot share room/utensil/clothes with you reduced the odds of being satisfied by $95 \%$ when compared to agreeing and disagreeing that friend or family member blames you for not getting better with an odds ratio of 5.65 compared to agreeing. Conclusion: This study unearthed existing gaps in levels of satisfaction. These shortfalls in the service delivery can be addressed according to the following recommendations below: Create a quick way for elderly patients to see a cli-
\end{abstract}


nician and give them priority, provide more work-related support awareness programs; Put more efforts towards counselling care takers or family members who help them to adhere or socialize with them.

\section{Keywords}

Quality of Life Model, Elderly HIV Patients, Patient Satisfaction, Adherence

\section{Introduction}

Effective antiretroviral therapy (ART) has increased survival in individuals with HIV, resulting in an increasing number of older individuals living with HIV. In the United States, among persons living with HIV at year-end 2013, 42\% were aged 50 years or older, $6 \%$ were age 65 or older, and trends suggest that these proportions will increase steadily [1]. Care of patients with HIV increasingly will involve adults 60 to 80 years of age, a population for which data from clinical trials or pharmacokinetic (PK) studies are very limited.

At the end of 2014, estimated 428,724 people aged 50 and over were living with diagnosed HIV in the United States. From 2010 to 2014, HIV diagnoses among all people aged 50 and over decreased by $10 \%$. In 2014, $40 \%$ of people aged 55 and older had late-stage infection (AIDS) at the time of HIV diagnosis [1].

According to CDC, the population of older adults living with HIV is increasing for the following reasons: 1) Many people who received an HIV diagnosis at a younger age are growing older. Life-long treatment with HIV medicines is helping these people live longer healthier lives. 2) Thousands of older people become infected with HIV every year.

In Germany, measuring satisfaction has been required since 2005 as an element of quality management [2]. Since 2002, the department of Health (DOH) has launched a national survey program in which all National Health Surveys (NHS) trusts in England have to survey patient satisfaction on an annual basis and report the results to their regulators [3]. Therefore, measurement of patient satisfaction is a legitimate indicator for improving the services and strategic goals for all healthcare organizations [4].

A study done in South Africa concluded that patient satisfaction is a fundamental indicator of equitable quality of care, to ensure customer satisfaction, attention to service quality is considered paramount for the employees at the clinics [5].

Patient satisfaction has been defined as the patient's "Personal evaluation of providers' ability of health care services". It reflects provider's ability to successfully deliver care that meets patients' expectations and needs [6]. Patient satisfaction with health care reflects the quality of services from the patients' perspective that supplements to traditional indicators such as survival outcomes or processes of care [7]. 
More than 2.5 million HIV positive adults over the age of 50 live in sub-Saharan Africa, accounting for more than half the people infected in this age cohort around the globe (UNAIDS, 2014) (HIV/AIDS 2015). Sub-Saharan Africa experiences the greatest HIV burden yet delay in free access to treatment and a lower life expectancy leaves a gap in both research attention and knowledge [8].

In Tanzania, a study on patient's satisfaction at a referral hospital observed a high level of satisfaction among respondents, mainly because of the hierarchical health care delivery system, whereby the referral hospital is at the apex with super-specialty services. However, a small proportion of patients were dissatisfied with long waiting time, high cost of treatment, and investigation charges [9].

Uganda, one of the growing economies in sub-Saharan Africa, has been experiencing a severe HIV/AIDS epidemic since the first Ugandan sera found positive for HIV-1 antibodies was detected in 1982 [10]. Currently, the prevalence of HIV infection in Uganda is $6.2 \%$ with approximately 1.2 million people aged 15 to 64 living with HIV [11]. Sentinel studies conducted by the Uganda Population-Based HIV Impact Assessment has included most sub-populations thought to be at high-risk for HIV and STIs but has excluded the elderly ( $>50$ years old) [11]. Recent reports from Africa and elsewhere have demonstrated that the diagnosis of HIV infection is recently occurring with increasing frequency in older people [12].

Unfortunately, high numbers of older people present late during the course of HIV infection and that most often older people are misdiagnosed as having age-related illness rather than HIV [13]. To understand satisfaction with life among elderly, the World Health Organization recommends the use of the Innovative Care for Chronic Conditions Framework [14] which is described as an expanded, internationalized adaptation of the earlier Chronic Care Model developed by Wagner and colleagues' [14]. The Innovative Care for Chronic Conditions Framework extends the Chronic Care Model by adding micro, meso and macro levels and incorporates six guiding principles: evidence-based decision making; population focus; prevention focus; quality focus; integration; flexibility and adaptability [14]. These levels extend the involvement of community and describe policies and financing as the drivers at the macro level [15]. Further studies which explicitly assess the implementation of the Innovative Care for Chronic Conditions Framework at health system level, have been suggested, however many components of it had been assessed in the literature that is related to the Chronic Care Model previously [16].

Survey of patient's satisfaction is an important tool to get feedback from the people. Also, it is a means of measuring the effectiveness of health care delivery in a particular area. [17]. Satisfied patients are more likely to comply with prescribed treatment and advice from the doctors, they are also more likely to return for additional care especially for those on long term treatment like human immunodeficiency virus/acquired immune deficiency syndrome [18]. Factors affecting satisfaction might be interlinked to many health-related factors. So, sa- 
tisfaction with life has become an important indicator for implementing HIV health-related intervention in a chronic illness model of HIV care.

\section{Materials and Methods}

\subsection{Study Design}

This was a cross sectional study carried out among elderly people ( $>50$ years old) attending Mulago HIV clinic, as stated by the WHO standard age cut-off of $>50$ years.

The design was chosen because it makes it possible to describe such attributes such as Illness related discrimination, Barriers to healthcare and social services and Physical wellbeing, social support \& coping.

\subsection{Study Area}

Mulago HIV clinic was launched in 2007 as an Immune Suppressive Syndrome (ISS) clinic for the treatment and diagnosis of HIV/AIDS. It operates as an out-patient HIV care center and one of the major referral centers in the country attending to over $5000 \mathrm{HIV}$ patients, this was considered a good area for the study since it serves a big population both from the Kampala metropolitan area and the nearby districts. I therefore expected a representative sample space made of elderly HIV patients originating from various social and ethnic groups as well as geographically distinct areas from the vast territory of the Greater Kampala region of Uganda and other regions.

\subsection{Sampling and Definition of Study Subjects}

The sample selection was pre-determined and purposive; i.e., the purposive sampling method was based on some pre-determined characteristic where the researcher selects the sample subjectively based on this characteristic [19]. However, the sample selection aimed to ensure that the spectrum of respondents is a representative of the elderly population as possible. The study population included averagely about 3778 HIV-infected elderly patients above 50 years currently receiving ART in the Mulago ISS Clinic and excluded persons with scientifically proven inabilities to give informed consent due to diminished cognitive abilities.

\subsection{Sample Size Determination}

Averagely, 25 elderly patients are seen at the clinic monthly and currently there about $2684 \mathrm{HIV}$-infected elderly patients above 50 years currently receiving ART in the Mulago ISS Clinic. The sample size was determined using a recognized sample size determination formula also called Solvin's formula shown below [20]. This is best suited when dealing with finite populations.

$$
n=N / 1+\left[N(e)^{2}\right]
$$

This formula is adopted by Yamane, where $n=$ minimum sample size $N=$ to- 
tal number of populations. Since in this study we wanted to achieve a confidence interval of $95 \%$, this made the error value (alpha level) " $e$ " to be constant at 0.05 . Using the known value of 2684 elderly patients, the study purposively sampled a minimum of three hundred forty-eight (348) consenting elderly patients utilizing HIV/AIDS Mulago clinic based on Solvin's sampling technique modelled into a formula.

\subsection{Data Collection Techniques}

Primary quantitative Data was collected using pre-tested interview schedules. These were administered to eligible clients at the clinic. The Likert scale [21], was used to collect quantitative data to measure the patients satisfaction with life, which is the dependent variable in this study, whereas data on the independent variables that is, 1) Illness related discrimination; 2) Barriers to healthcare and social services; 3) Physical wellbeing, social support and coping; were collected using a set of questionnaires to answer questions on client views regarding the quality of elderly services offered at the HIV/AIDS clinic. Qualitative data was collected using a focus group discussion approach from elderly patients attending to Mulago HIV clinic.

\subsection{Study Variables}

\subsubsection{Dependent Variable}

Patient's satisfaction is the patient's perception of care received compared with the care expected by them. The dependent variable, satisfaction with life was assessed as previously done [22]. The dependent variable (satisfaction with life) was a binary outcome.

\subsubsection{Independent Variable}

The following independent variables were measured to assess elderly patient satisfaction with life;

1) Illness related discrimination

a) Discrimination from friends and family,

b) Discrimination at work,

c) Discrimination by the healthcare provider.

2) Barriers to healthcare and social services

a) Stigma,

b) Financial barriers,

c) Geographical barriers,

d) Co-morbidities,

e) Health service provider barriers,

f) Community HIV knowledge barriers,

g) Employment challenges.

3) Physical wellbeing, social support and coping

a) Physical inactivity,

b) Number of chronic illnesses, 

c) Medication adherence,
d) Emotional support,
e) Institutional support,
f) Community support.

\subsection{Data Analysis}

Data was double entered into EPIDATA and validated for consistence. This was then exported to STATA version 14.2 for analysis. All missing data was reported as missing and ignored in analysis. At descriptive analysis level, findings were described in terms of frequencies and percentages and results were summarized in tables and figures where applicable. The dependent outcome, satisfaction with life was calculated as previously done [22]. Briefly, the Satisfaction with Life Scale consists of 5 items that relate to global satisfaction with life; 1) In most ways my life is close to my ideal, 2) The conditions of my life are excellent, 3) I am satisfied with my life, 4) I have achieved the important things I wanted, and 5) If I could live my life over, I wouldn't change anything. Each item was scored on a scale from one to seven points, giving a total score range of 5 - 35 points, where a high score indicated satisfaction with life. The outcome variable, satisfaction with life was categorized into satisfied with life (satisfaction with a score of 20 and above) and not satisfied with life (satisfaction score below 20).

Bivariate associations between the outcome and the independent variables was got using logistic regression. Variables with a p-value $<0.2$ were taken for multivariate to see which variables were significant after adjusting for other factors. Variables with $\mathrm{p}$-value $<0.05$ at multivariate were considered significant. Participants' opinions about life satisfaction were summarized into percentages and presented in bar graphs.

Qualitative data collected from focus group discussions was transcribed from audio recordings. Further analysis was done using coded word-processed text organized and analyzed using content and factor analysis with Atlas/ti software. Data was divided into meaningful analytical units and marked with descriptive words. The codes were merged into larger categories and themes. Content from each coded group were summarized and illustrated with direct quotes from the discussion. A $10 \%$ back translation was done for quality control.

\subsection{Ethical Considerations}

This research was carried out in accordance with the ethical principles as stated in by Angell and Marcia in a journal "the ethics of clinical research in a third world" [23]; and other applicable regulatory pre-requisites. Prior to commencing this research, permission and approval was sought from International Health Sciences University and Mulago HIV Clinic management office. A letter of introduction was obtained from CIU and presented to the office of the Clinic Manager at Mulago HIV Clinic where the study was conducted.

Patient information and informed consent: Patients were requested to give informed consent prior to joining the study after being explained clearly in the 
language they could understand the purpose of the study, the expected benefits and risks thereof. Refusal to participate in the study did not deny the patients appropriate management for their illness as per hospital protocol. Fundamentally, all patients were at liberty to terminate their participation in the study without any consequences. All information from patients was strictly confidential and no personal details were recorded throughout the study.

\section{Results}

\subsection{Response Rate}

A total of 353 respondents were sampled and interviewed using a questionnaire and all the respondents were able to provide answers for all the items in the questionnaire, giving a response rate of $100 \%$.

Response Rate $=$ Total number of copies of the questionnaire given out/total number of respondents $\times 100$

$$
\begin{aligned}
& =353 / 353 \times 100 \\
& =100 \% .
\end{aligned}
$$

\subsection{Demographic Characteristics}

The highest proportion 242/353 (68.6\%) of respondents is in the age group of 50 - 59 years, with more than half 198/353 (56.1\%) of the respondents being female. The highest proportion of the respondents153/353 (43.3\%) of the respondents was married. In terms of employment, the highest proportion of respondents $216 / 353(61.2 \%)$ was employed and slightly more than half $179 / 353(50.7 \%)$ of the respondents had primary level of education as the highest level of education attained (Table 1).

\subsubsection{Satisfaction with Life (Dependent Variable)}

The highest proportion 126/353 (35.7\%) of respondents agreed that their life is close to ideal. A total of $118 / 353$ (33.4\%) of the respondents agreed to the fact that the conditions in their lives were excellent. The highest proportion 99/353 (28\%) of respondents agreed that they were satisfied with health condition. A total of $97 / 353(27.5 \%)$ of the respondents were not sure whether they had achieved important things in life. 91/353 (21.5\%) of the respondents slightly disagreed to the fact that they wouldn't change anything in their life (Table 2).

Table 1. Demographic characteristics of the respondents.

\begin{tabular}{ccc}
\hline Variable & Frequency $(\mathbf{n}=\mathbf{3 5 3})$ & Percentage $(\%)$ \\
\hline Age group & & \\
\hline Below 50 & 1 & 0.3 \\
$50-59$ & 242 & 68.6 \\
$60-69$ & 86 & 24.4 \\
$70-79$ & 17 & 4.8 \\
80 and above & 7 & 1.9 \\
\hline
\end{tabular}




\section{Continued}

\begin{tabular}{ccc}
\hline Sex & & \\
Male & 155 & 43.9 \\
Female & 198 & 56.1 \\
\hline Marital status & & 1.1 \\
\hline Single & 4 & 43.3 \\
Married & 153 & 13.3 \\
Separated & 47 & 12.7 \\
Divorced & 45 & 29.5 \\
Widowed & 104 & \\
\hline Employment & & 61.2 \\
\hline Employed & 216 & 33.1 \\
Not employed & 117 & 5.6 \\
Retired & 20 & 11.9 \\
\hline Education level & & 50.7 \\
\hline None & 42 & 26.1 \\
Primary & 179 & 11.3 \\
Secondary & 92 &
\end{tabular}

Source: Primary data from respondents.

Table 2. Responses in relation to satisfaction with life.

\begin{tabular}{ccc}
\hline Variable & Frequency $(\mathbf{n}=\mathbf{3 5 3})$ & Percentage (\%) \\
\hline Life is close to ideal & & \\
\hline Strongly disagree & 32 & 9.1 \\
Disagree & 54 & 15.3 \\
Slightly disagree & 13 & 3.7 \\
Neither agree or disagree & 30 & 8.5 \\
Slightly agree & 79 & 22.4 \\
Agree & 126 & 35.7 \\
Strongly agree & 19 & 5.4 \\
\hline Conditions of life are excellent & & 11.6 \\
Strongly disagree & 41 & 13.3 \\
Disagree & 47 & 5.7 \\
Slightly disagree & 20 & 10.2 \\
Neither agree or disagree & 36 & 23.5 \\
Slightly agree & 83 & 33.4 \\
Agree & 118 & 2.3 \\
Strongly agree & 8 &
\end{tabular}




\section{Continued}

\begin{tabular}{|c|c|c|}
\hline Satisfied with life & & \\
\hline Strongly disagree & 43 & 12.2 \\
\hline Disagree & 67 & 19.0 \\
\hline Slightly disagree & 10 & 2.8 \\
\hline Neither agree or disagree & 22 & 6.2 \\
\hline Slightly agree & 78 & 22.1 \\
\hline Agree & 99 & 28.0 \\
\hline Strongly agree & 34 & 9.6 \\
\hline \multicolumn{3}{|l|}{ Have important things in life } \\
\hline Strongly disagree & 45 & 12.7 \\
\hline Disagree & 53 & 15.0 \\
\hline Slightly disagree & 21 & 5.9 \\
\hline Neither agree or disagree & 24 & 6.8 \\
\hline Slightly agree & 97 & 27.5 \\
\hline Agree & 92 & 26.1 \\
\hline Strongly agree & 24 & 5.9 \\
\hline \multicolumn{3}{|c|}{ Wouldn't change anything in life } \\
\hline Strongly disagree & 40 & 11.3 \\
\hline Disagree & 74 & 21.0 \\
\hline Slightly disagree & 91 & 25.8 \\
\hline Neither agree or disagree & 66 & 18.7 \\
\hline Slightly agree & 43 & 12.2 \\
\hline Agree & 26 & 7.4 \\
\hline Strongly agree & 13 & 3.7 \\
\hline
\end{tabular}

Source: Primary data from respondents.

\subsubsection{Dependent Variable (Overall Satisfaction with Life)}

To measure the overall satisfaction with life a 5-item scale was designed to measure respondent's judgment of one's life satisfaction (Table 3). Participants indicated how much they agree or disagree with each of the 5 items using a 7 point scale that ranges from 7 strongly agree to 1 strongly disagree. The overall satisfaction with life was measured as a binary outcome, either satisfied or not satisfied. After summing up the totals, individuals with total scores above 20 were considered satisfied with life while the individuals with total scores below 20 were considered not to be satisfied with life [22] as illustrated in Figure 1 below; From Figure 1, the highest proportion $(60.1 \%)$ of respondents were satisfied with life. 
Table 3. Showing satisfaction with life scale (SWLS).

\begin{tabular}{|c|c|c|c|c|c|c|c|}
\hline & $\begin{array}{l}\text { Strongly } \\
\text { Agree }\end{array}$ & Agree & $\begin{array}{l}\text { Slightly } \\
\text { Agree }\end{array}$ & $\begin{array}{l}\text { Neither Agree } \\
\text { or Disagree }\end{array}$ & $\begin{array}{l}\text { Slightly } \\
\text { disagree }\end{array}$ & Disagree & $\begin{array}{l}\text { Strongly } \\
\text { Disagree }\end{array}$ \\
\hline $\begin{array}{l}\text { In most ways my life is } \\
\text { close to my ideal }\end{array}$ & 7 & 6 & 5 & 4 & 3 & 2 & 1 \\
\hline $\begin{array}{l}\text { The conditions of my } \\
\text { life are excellent }\end{array}$ & 7 & 6 & 5 & 4 & 3 & 2 & 1 \\
\hline I am satisfied with my life. & 7 & 6 & 5 & 4 & 3 & 2 & 1 \\
\hline $\begin{array}{l}\text { So far, I have gotten the } \\
\text { important things I want in life. }\end{array}$ & 7 & 6 & 5 & 4 & 3 & 2 & 1 \\
\hline $\begin{array}{l}\text { If I could live my life over, } \\
\text { I would change almost nothing. }\end{array}$ & 7 & 6 & 5 & 4 & 3 & 2 & 1 \\
\hline
\end{tabular}

Diener, et al. (1985) (sum up scores are 31 - 35 Extremely satisfied, 26 - 30 Satisfied, 21 - 25 Slightly satisfied, 20 Neutral , 15 - 19 Slightly dissatisfied, 10 - 14 Dissatisfied, 5 - 9 Extremely dissatisfied).

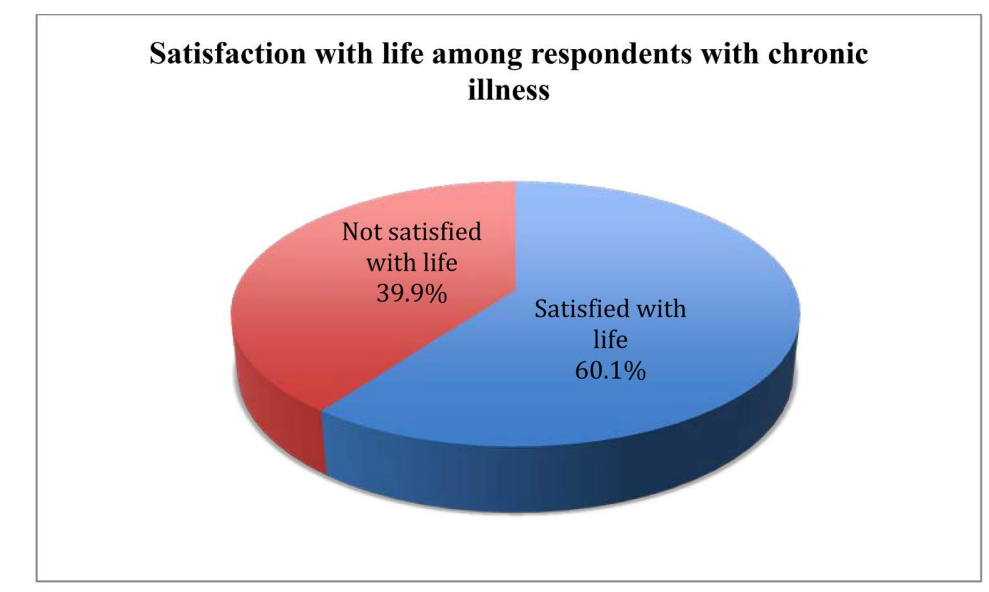

Figure 1. Satisfaction with life among respondents. Source: primary data from respondents.

\subsubsection{Descriptive Analysis of Independent Variables Described in Terms of Frequencies and Percentages and the Dependent Outcome of Satisfaction with Life (Tables 4-6 Figure 2, Figure 3)}

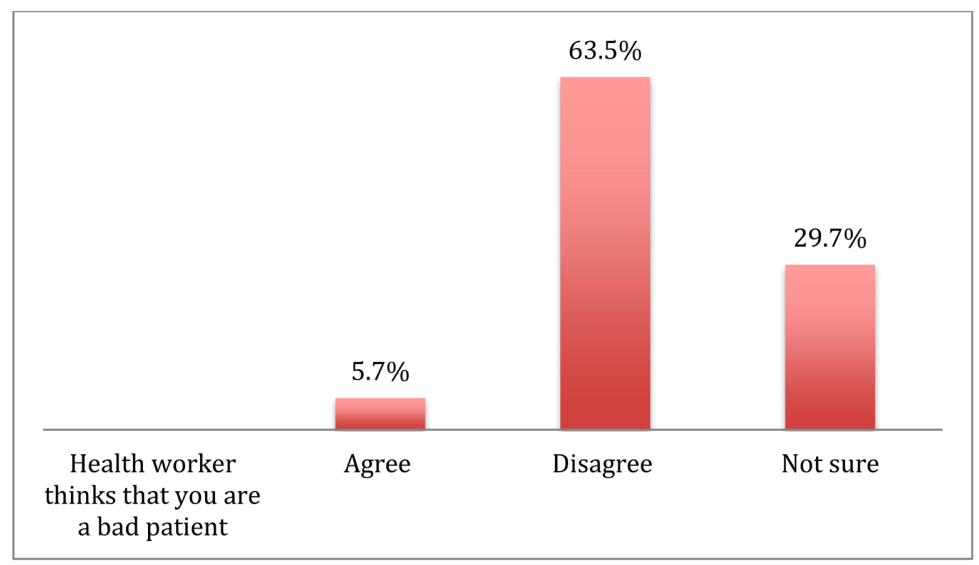

Figure 2. Response regarding to health worker thinks you are a bad patient. 


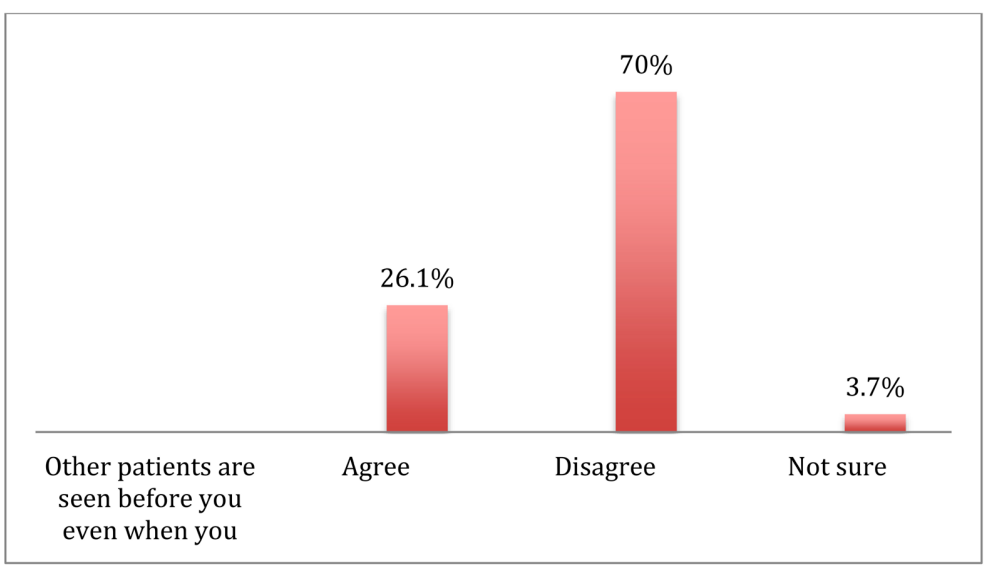

Figure 3. Responses regarding to attendance to patients even when they come early at facility.

Table 4. Responses in relation to illness related discrimination.

\begin{tabular}{|c|c|c|}
\hline Variable & Frequency $(n=353)$ & Percentage (\%) \\
\hline \multicolumn{3}{|c|}{$\begin{array}{l}\text { Friends or family think you are } \\
\text { responsible for your chronic illness }\end{array}$} \\
\hline Agree & 53 & 15.0 \\
\hline Disagree & 224 & 63.5 \\
\hline Not sure & 76 & 21.5 \\
\hline \multicolumn{3}{|c|}{$\begin{array}{l}\text { A friend or family member } \\
\text { doesn't think highly of you }\end{array}$} \\
\hline Agree & 13 & 3.7 \\
\hline Disagree & 249 & 70.5 \\
\hline Not sure & 90 & 25.5 \\
\hline \multicolumn{3}{|c|}{$\begin{array}{l}\text { A friend or family member } \\
\text { blames you for not getting better }\end{array}$} \\
\hline Agree & 22 & 6.2 \\
\hline Disagree & 234 & 66.3 \\
\hline Not sure & 92 & 26.1 \\
\hline \multicolumn{3}{|c|}{$\begin{array}{l}\text { A friend or family member cant share } \\
\text { either a room, clothes or utensils with you }\end{array}$} \\
\hline Agree & 14 & 4.0 \\
\hline Disagree & 276 & 78.2 \\
\hline Not sure & 51 & 14.4 \\
\hline \multicolumn{3}{|c|}{$\begin{array}{l}\text { Someone at work thinks you can't } \\
\text { fulfill your work responsibilities }\end{array}$} \\
\hline Agree & 11 & 3.1 \\
\hline Disagree & 153 & 43.3 \\
\hline Not sure & 75 & 21.2 \\
\hline
\end{tabular}




\section{Continued}

\begin{tabular}{|c|c|c|}
\hline \multicolumn{3}{|c|}{ job to someone else } \\
\hline Agree & 31 & 8.8 \\
\hline Disagree & 102 & 28.9 \\
\hline Not sure & 93 & 26.3 \\
\hline \multicolumn{3}{|c|}{ Your employer can never promote you } \\
\hline Agree & 92 & 26.1 \\
\hline Disagree & 122 & 34.6 \\
\hline Not sure & 25 & 7.1 \\
\hline \multicolumn{3}{|c|}{$\begin{array}{l}\text { Health worker blame you } \\
\text { for not getting better }\end{array}$} \\
\hline Agree & 15 & 4.2 \\
\hline Disagree & 256 & 72.5 \\
\hline Not sure & 73 & 20.7 \\
\hline Frustrated & 11 & 3.1 \\
\hline Agree & 250 & 70.8 \\
\hline Disagree & 91 & 25.8 \\
\hline \multicolumn{3}{|l|}{ Not sure } \\
\hline \multicolumn{3}{|c|}{ Health worker gives you poor care } \\
\hline Agree & 9 & 2.5 \\
\hline Disagree & 256 & 72.5 \\
\hline Not sure & 81 & 22.9 \\
\hline
\end{tabular}

Source: Primary data from respondents.

Table 5. Responses in relation to barriers to health care and social services.

\begin{tabular}{ccc}
\hline Variable & Frequency $(\mathbf{n}=\mathbf{3 5 3})$ Percentage (\%) \\
\hline Don't want to be seen visiting an HIV clinic & & \\
\hline Agree & 92 & 26.1 \\
Disagree & 247 & 70.2 \\
Not sure & 13 & 3.7 \\
\hline I can't disclose my HIV status & & 12.2 \\
Agree & 43 & 85.8 \\
Disagree & 303 & 1.7 \\
Not sure & 6 & \\
\hline Not considered for community activities & & 10.2 \\
Agree & 36 & 79.0 \\
Disagree & 279 & 10.8 \\
\hline Not sure & 38 & \\
\hline
\end{tabular}




\section{Continued}

\begin{tabular}{|c|c|c|}
\hline $\begin{array}{c}\text { It is hard to find a job when } \\
\text { you are HIV positive }\end{array}$ & & \\
\hline Agree & 101 & 28.6 \\
\hline Disagree & 167 & 47.3 \\
\hline Not sure & 84 & 23.8 \\
\hline \multicolumn{3}{|c|}{ Not allowed to socialize with members } \\
\hline Agree & 16 & 4.5 \\
\hline Disagree & 290 & 82.2 \\
\hline Not sure & 41 & 11.6 \\
\hline \multicolumn{3}{|l|}{ Employed } \\
\hline Yes & 228 & 64.6 \\
\hline No & 124 & 35.1 \\
\hline \multicolumn{3}{|l|}{ Payment for HIV services } \\
\hline Access free services & 353 & 100.0 \\
\hline \multicolumn{3}{|l|}{ How far is the nearest HIV clinic? } \\
\hline Below 5 km & 110 & 31.2 \\
\hline Above $5 \mathrm{~km}$ & 243 & 68.8 \\
\hline \multicolumn{3}{|c|}{ Other chronic illnesses other than HIV? } \\
\hline Agree & 120 & 34.0 \\
\hline Disagree & 232 & 65.7 \\
\hline Not sure & 1 & 0.03 \\
\hline \multicolumn{3}{|c|}{ Public knowledge on HIV is inadequate } \\
\hline Agree & 178 & 50.4 \\
\hline Disagree & 117 & 33.1 \\
\hline Not sure & 54 & 15.3 \\
\hline \multicolumn{3}{|c|}{ No health workers knowledge on HIV } \\
\hline Agree & 5 & 1.4 \\
\hline Disagree & 303 & 85.8 \\
\hline Not sure & 38 & 10.8 \\
\hline
\end{tabular}

Source: Primary data from respondents.

Table 6. Responses to physical wellbeing, social support and coping.

\section{Variable}

Frequency $(n=353)$ Percentage $(\%)$

Are you physically unable to perform certain activities?

$\begin{array}{lll}\text { Yes } & 117 & 33.7 \\ \text { No } & 230 & 66.3\end{array}$




\section{Continued}

Do you suffer from any chronic illness?

\begin{tabular}{ccc}
\hline Yes & 184 & 52.1 \\
No & 162 & 45.9 \\
Am not sure & 7 & 2 \\
\hline Do you adhere to your medication? & 319 & \\
\hline Always & 12 & 90.4 \\
Sometimes & 22 & 3.4 \\
Rarely & 6.2 \\
\hline
\end{tabular}

Who helps you to adhere

to medication?

$\begin{array}{ccc}\text { Friend/relative } & 216 & 61.4 \\ \text { Colleague } & 14 & 4 \\ \text { Health worker } & 45 & 12.8 \\ \text { Myself } & 77 & 21.9\end{array}$

Does your religion help you

in coping with the disease?

$\begin{array}{ccc}\text { Yes } & 321 & 92.2 \\ \text { No } & 27 & 7.8\end{array}$

I accepted my condition and am okay

$\begin{array}{lcc}\text { Yes } & 299 & 86.2 \\ \text { No } & 48 & 13.8\end{array}$

Do you find substance use helpful in coping with the illness?

\begin{tabular}{ccc}
\hline Yes & 165 & 47.1 \\
No & 185 & 52.9 \\
\hline $\begin{array}{c}\text { Do you sometimes blame } \\
\text { yourself for being ill? }\end{array}$ & & \\
\hline Yes & 109 & 31.6 \\
No & 236 & 68.4 \\
\hline $\begin{array}{c}\text { Do you sometimes believe } \\
\text { that you may not be sick? }\end{array}$ & 89 & 25.2 \\
\hline No & 205 & 58.1 \\
\hline $\begin{array}{c}\text { Haven't thought of it } \\
\text { Do you have people that help } \\
\text { to lift you to a higher ground? }\end{array}$ & 59 & 16.7 \\
\hline Yes & 290 & 83.1 \\
No & 59 & 16.9 \\
\hline
\end{tabular}


Continued

\begin{tabular}{ccc}
\hline $\begin{array}{c}\text { For those employed, do you } \\
\text { get any institutional support? }\end{array}$ & \\
\hline Yes & 50 & 15.4 \\
No & 275 & 84.6 \\
\hline $\begin{array}{c}\text { Does your community support } \\
\text { you in anyway in regard to your illness? }\end{array}$ & \\
\hline Yes & 89 & 25.5 \\
No & 260 & 74.5 \\
\hline
\end{tabular}

Source: Primary data from respondents.

\subsection{Factors Associated with Satisfaction with Life}

Bivariate associations. (Tables 7-10)

The only variables that were significantly associated at multivariate level are 1) Disagreeing that other patients are seen before you when you are first to arrive, which had an odds ratio of 2.87 compared to agreeing, disagreeing that your employer can never promote you which had an odds ratio of 6.87 compared to agreeing, not being sure whether friend or family member cannot share room/ utensil/clothes with you with an odds ratio of 0.05 and disagreeing that friend or family member blames you for not getting better with an odds ratio of 5.65 compared to agreeing.

\subsection{Qualitative Data}

\subsubsection{Describe Your Experience at Mulago HIV Clinic}

A total of 10 elderly patients selected from the facility were involved in a focus group discussion and they had several comments in relation to their experience at the HIV clinic and how it affects their satisfaction.

"We come very early to the clinic, but we wait for long in the lines when doctors have not arrived, like it is 9.30 am and no one has attended to us, yet we arrived at 7.00 am, we hear that they are in a meeting but for how long should we wait".

"Some of us when they call numbers, we are not sure of the numbers because we can't read them well and when you delay responding they attend to another patient and you keep waiting". So, this procedure of calling numbers need to be addressed and considered for us elderly who can't read.

"Some health workers can be very rude; and blame us of old age and our illness that we should be knowing how to take care of ourselves and not fall sick". "However, majority are polite, caring and pay attention to our medical needs and give us a lot of advice.

"Most of the health care workers go for break and lunch for long and leave our files on the desks, yet we have also just escaped from our work places. So, we fear for our jobs if it is to continue this way". 
Table 7. Illness related discrimination.

\begin{tabular}{|c|c|c|c|}
\hline Variable & OR & $\mathrm{p}$ value & $\begin{array}{l}\text { 95\% Confidence } \\
\text { Interval }\end{array}$ \\
\hline $\begin{array}{l}\text { Friend or family member } \\
\text { thinks that you are responsible } \\
\text { for your chronic illness }\end{array}$ & & $<0.001$ & \\
\hline Agree & Ref & & \\
\hline Disagree & 6.43 & $<0.001$ & $3.37,12.29$ \\
\hline Not sure & 0.84 & 0.657 & $0.40,1.79$ \\
\hline $\begin{array}{l}\text { Friend or family member } \\
\text { does not think highly of me }\end{array}$ & & $<0.001$ & \\
\hline Agree & Ref & & \\
\hline Disagree & 2.19 & 0.172 & $0.71,6.75$ \\
\hline Not sure & 0.37 & 0.096 & $0.11,1.20$ \\
\hline $\begin{array}{l}\text { Friend or family member } \\
\text { blames you for not getting better }\end{array}$ & & $<0.001$ & \\
\hline Agree & Ref & & \\
\hline Disagree & 4.96 & 0.001 & $1.99,12.41$ \\
\hline Not sure & 0.85 & 0.737 & $0.32,2.24$ \\
\hline $\begin{array}{l}\text { Friend or family member cant share } \\
\text { room/utensils/clothes with you }\end{array}$ & & $<0.001$ & \\
\hline Agree & Ref & & \\
\hline Disagree & 1.38 & 0.558 & $0.47,4.1$ \\
\hline Not sure & 0.84 & 0.061 & $0.09,1.06$ \\
\hline $\begin{array}{l}\text { Someone at work thinks that you } \\
\text { cannot fulfill your work responsibilities }\end{array}$ & & 0.001 & \\
\hline Agree & Ref & & \\
\hline Disagree & 5.03 & 0.021 & $1.28,19.76$ \\
\hline Not sure & 2.1 & 0.301 & $0.52,8.52$ \\
\hline $\begin{array}{l}\text { Your employer assigns a } \\
\text { challenging project to someone else }\end{array}$ & & $<0.001$ & \\
\hline Agree & Ref & & \\
\hline Disagree & 2.96 & 0.01 & $1.29,6.80$ \\
\hline Not sure & 0.67 & 0.344 & $0.30,1.53$ \\
\hline $\begin{array}{l}\text { Your employer can never } \\
\text { promote you }\end{array}$ & & $<0.001$ & \\
\hline Agree & Ref & & \\
\hline Disagree & 8.47 & $<0.001$ & $4.56,15.74$ \\
\hline Not sure & 2.61 & 0.038 & $1.06,6.44$ \\
\hline
\end{tabular}


Continued

\begin{tabular}{|c|c|c|c|}
\hline $\begin{array}{l}\text { Healthcare worker blames you } \\
\text { for not getting better }\end{array}$ & \multicolumn{3}{|c|}{$<0.001$} \\
\hline Agree & Ref & & \\
\hline Disagree & 1.73 & 0.305 & $0.61,4.93$ \\
\hline Not sure & 0.58 & 0.334 & $0.19,1.76$ \\
\hline $\begin{array}{l}\text { Healthcare worker is frustrated } \\
\text { with you }\end{array}$ & & $<0.001$ & \\
\hline Agree & Ref & & \\
\hline Disagree & 3.93 & 0.033 & $1.12,13.83$ \\
\hline Not sure & 1.15 & 0.838 & $0.31,4.20$ \\
\hline $\begin{array}{l}\text { Healthcare worker gives you } \\
\text { poor care }\end{array}$ & & $<0.001$ & \\
\hline Agree & Ref & & \\
\hline Disagree & 8.77 & 0.008 & $1.78,43.23$ \\
\hline Not sure & 1.47 & 0.644 & $0.29,7.61$ \\
\hline $\begin{array}{l}\text { Healthcare worker will } \\
\text { think that you are a bad patient }\end{array}$ & & $<0.001$ & \\
\hline Agree & Ref & & \\
\hline Disagree & 1.91 & 0.179 & $0.74,4.9$ \\
\hline Not sure & 0.31 & 0.018 & $0.11,0.82$ \\
\hline $\begin{array}{l}\text { Other patients are seen before } \\
\text { you even when you are first to arrive }\end{array}$ & & $<0.001$ & \\
\hline Agree & Ref & & \\
\hline Disagree & 6.01 & $<0.001$ & $3.56,10.15$ \\
\hline Not sure & 1.27 & 0.585 & $0.53,3.04$ \\
\hline
\end{tabular}

Table 8. Barriers to healthcare and social services.

\begin{tabular}{cccc}
\hline Variable & OR & p value $\begin{array}{c}\text { 95\% Confidence } \\
\text { Interval }\end{array}$ \\
\hline $\begin{array}{c}\text { Don't want people to see me } \\
\text { visiting an HIV clinic }\end{array}$ & & $<0.001$ & \\
\hline Agree & Ref & & \\
Disagree & 2.79 & $<0.001$ & $1.70,4.55$ \\
Not sure & 2.17 & 0.201 & $0.66,7.16$ \\
\hline $\begin{array}{c}\text { Can't disclose my HIV status } \\
\text { to my family members }\end{array}$ & 0.068 & \\
Agree & & & \\
Disagree & Ref & & $1.11,4.05$ \\
Not sure & 2.12 & 0.022 & $0.42,15.30$ \\
\hline
\end{tabular}




\section{Continued}

\begin{tabular}{|c|c|c|c|}
\hline $\begin{array}{l}\text { Community doesn't consider me when it } \\
\text { comes to community activities }\end{array}$ & & 0.008 & \\
\hline Agree & Ref & & \\
\hline Disagree & 3.07 & 0.02 & $1.49,6.32$ \\
\hline Not sure & 2.71 & 0.038 & $1.06,6.95$ \\
\hline $\begin{array}{l}\text { It's hard to find a job when you are } \\
\text { HIV positive }\end{array}$ & & 0.373 & \\
\hline Agree & Ref & & \\
\hline Disagree & 1.38 & 0.207 & $0.84,2.28$ \\
\hline Not sure & 1.43 & 0.236 & $0.79,2.58$ \\
\hline $\begin{array}{l}\text { Community environment doesn't allow me to } \\
\text { socialize with members }\end{array}$ & & 0.226 & \\
\hline Agree & Ref & & \\
\hline Disagree & 0.52 & 0.271 & $0.16,1.66$ \\
\hline Not sure & 0.35 & 0.11 & $0.10,1.27$ \\
\hline Are you employed & & 0.094 & \\
\hline Yes & Ref & & \\
\hline No & 1.47 & 0.096 & $0.93,2.32$ \\
\hline $\begin{array}{l}\text { How far is the nearest HIV clinic when } \\
\text { you access services from your residence }\end{array}$ & & 0.136 & \\
\hline Below $5 \mathrm{Km}$ & Ref & & \\
\hline Above $5 \mathrm{Km}$ & 1.42 & 0.135 & $0.90,2.24$ \\
\hline $\begin{array}{l}\text { Do you have any other chronic } \\
\text { illness other than HIV }\end{array}$ & & $<0.001$ & \\
\hline Yes & Ref & & \\
\hline No & 2.39 & $<0.001$ & $1.52,3.76$ \\
\hline Public knowledge on HIV is inadequate & & $<0.001$ & \\
\hline Agree & Ref & & \\
\hline Disagree & 0.34 & $<0.001$ & $0.21,0.56$ \\
\hline Not sure & 0.29 & $<0.001$ & $0.15,0.54$ \\
\hline $\begin{array}{l}\text { HIV healthcare workers are not adequately } \\
\text { knowledgeable regarding HIV }\end{array}$ & & $<0.001$ & \\
\hline Agree & Ref & & \\
\hline Disagree & 0.49 & 0.52 & $0.05,4.40$ \\
\hline Not sure & 0.07 & 0.022 & $0.01,0.68$ \\
\hline $\begin{array}{l}\text { My HIV treatment facility changes } \\
\text { its location very often }\end{array}$ & & 0.002 & \\
\hline Agree & Ref & & \\
\hline Disagree & 1.7 & 0.709 & $0.11,27.39$ \\
\hline Not sure & 0.31 & 0.439 & $0.02,5.96$ \\
\hline
\end{tabular}


Table 9. Physical wellbeing, social support and coping.

\begin{tabular}{|c|c|c|c|}
\hline Variable & OR & $\mathrm{p}$ value & $\begin{array}{l}\text { 95\% Confidence } \\
\text { Interval }\end{array}$ \\
\hline \multicolumn{4}{|l|}{$\begin{array}{c}\text { Are you physically unable to perform } \\
\text { certain activities }\end{array}$} \\
\hline Yes & Ref & & \\
\hline No & 0.86 & 0.507 & $0.54,1.35$ \\
\hline \multicolumn{4}{|l|}{ Do you suffer from any chronic illness } \\
\hline Yes & Ref & & \\
\hline No & 6.37 & $<0.001$ & $3.88,10.48$ \\
\hline Do you adhere to your medication & & 0.838 & \\
\hline Always & Ref & & \\
\hline Sometimes & 0.9 & 0.863 & $0.28,2.90$ \\
\hline Rarely & 0.77 & 0.562 & $0.32,1.84$ \\
\hline Who helps you adhere to medication & & $<0.001$ & \\
\hline Friend/relative & Ref & & \\
\hline Colleague & 0.33 & 0.07 & $0.10,1.09$ \\
\hline Health worker & 0.38 & 0.005 & $0.19,0.74$ \\
\hline Myself & 63.12 & $<0.001$ & $8.62,462.17$ \\
\hline \multicolumn{4}{|l|}{$\begin{array}{l}\text { Does your religion help you in coping } \\
\text { with the disease }\end{array}$} \\
\hline Yes & Ref & & \\
\hline No & 0.35 & $<0.001$ & $1.34,2.10$ \\
\hline \multicolumn{4}{|l|}{ I accepted my condition and am okay } \\
\hline Yes & Ref & & \\
\hline No & 0.37 & $<0.001$ & $1.40,2.10$ \\
\hline
\end{tabular}

Do you find substance use helpful in coping with the illness

\begin{tabular}{cccc}
\hline $\begin{array}{c}\text { Yes } \\
\text { No }\end{array}$ & $\begin{array}{c}\text { Ref } \\
\text { ( }\end{array}$ & & \\
\hline $\begin{array}{c}\text { Do you sometimes blame yourself for } \\
\text { being ill }\end{array}$ & & & \\
\hline Yes & & & \\
No & Ref & & \\
\hline $\begin{array}{c}\text { Do you sometimes believe that you may } \\
\text { not be sick }\end{array}$ & 1.81 & 0.012 & $1.14,2.87$ \\
\hline Yes & & $<0.001$ & \\
No & Ref & & \\
\hline Am not sure & 2.07 & 0.006 & $1.23,3.47$ \\
\hline & 0.33 & 0.002 & $0.16,0.67$ \\
\hline
\end{tabular}




\section{Continued}

\begin{tabular}{cccc}
\hline $\begin{array}{l}\text { Do you have people that help } \\
\text { to lift you to a higher ground }\end{array}$ & & & \\
Yes & Ref & & \\
No & 2.37 & 0.009 & $1.24,4.51$ \\
\hline $\begin{array}{c}\text { For those employed, do you get } \\
\text { any institutional support }\end{array}$ & & & \\
\hline Yes & Ref & & \\
No & 1.11 & 0.749 & $0.59,2.06$ \\
\hline $\begin{array}{c}\text { Does your community support } \\
\text { you in anyway, in regard to your illness }\end{array}$ & & & \\
\hline Yes & Ref & & \\
\hline No & 2.25 & 0.001 & $1.38,3.67$ \\
\hline
\end{tabular}

Table 10. Multivariate analysis of the factors associated with patient satisfaction with life.

\begin{tabular}{|c|c|c|c|}
\hline Variable & $\begin{array}{l}\text { Adjusted } \\
\text { OR }\end{array}$ & $\mathrm{p}$ value & $\begin{array}{l}\text { 95\% Confidence } \\
\text { Interval }\end{array}$ \\
\hline \multicolumn{4}{|c|}{$\begin{array}{l}\text { Other patients are seen before you } \\
\text { even when you are first to arrive }\end{array}$} \\
\hline Agree & Ref & & \\
\hline Disagree & 2.87 & 0.005 & $1.37,6.01$ \\
\hline Not sure & 1.02 & 0.972 & $0.26,3.97$ \\
\hline \multicolumn{4}{|c|}{ Your employer can never promote you } \\
\hline Agree & Ref & & \\
\hline Disagree & 6.87 & $<0.001$ & $4.56,15.74$ \\
\hline Not sure & 1.92 & 0.241 & $1.06,6.44$ \\
\hline \multicolumn{4}{|c|}{$\begin{array}{l}\text { Friend or family member can't share } \\
\text { room/utensils/clothes with you }\end{array}$} \\
\hline Agree & Ref & & \\
\hline Disagree & 0.24 & 0.14 & $0.04,1.60$ \\
\hline Not sure & 0.05 & 0.005 & $0.01,0.42$ \\
\hline \multicolumn{4}{|c|}{$\begin{array}{l}\text { Friend or family member blames } \\
\text { you for not getting better }\end{array}$} \\
\hline Agree & Ref & & \\
\hline Disagree & 5.65 & 0.018 & $1.35,23.64$ \\
\hline Not sure & 1.35 & 0.683 & $0.32,5.71$ \\
\hline
\end{tabular}

"So many times, we complain of other illnesses like pressure and diabetes but we can't get help on medication and instead they tell us to go and buy the drugs when we do not have money" 


\subsubsection{What Barriers to Health Care and Socio Services Would You Recommend to Be Addressed to Increase Patient Satisfaction}

Majority of the participants believed that improving on the time of attending to them at the clinic to reduce on delays would increase patient satisfaction, and also the need to sensitize community because they can't socialize freely in community.

"We really wait for health workers, if they can try coming early and reduce on the unnecessary movements and talking to each other in their rooms, we wouldn't have to sit for long waiting for them".

"We need support from our family members and relatives, but we can't disclose to them because when we do they stop coming to visit us, apart from our own children they keep supporting us but our relatives and community members know we are infected they tend to isolate you and stop communication slowly".

"We would like to be separated from the young ones (adolescents) at the clinic if possible, because sometimes you sit in the same corridors with them and they keep looking at you, probably thinking where you got the infection from. At least if we could have a separate tent"

"If they can support us with other medication apart from HIV drugs when we are sick, it will help us other than telling us to go buy them. let the government support the clinic with other drugs"

\subsubsection{When Do You Know You Are Satisfied with Life?}

More than a half $(8 / 10)$ of the participants claimed to be satisfied with life as noted below;

"When we have access to social services and support in our communities and from our family members".

"When we have no worries, pain or no deformities and have access to our clinic and HIV medication any time"

When we come here at the clinic and spend less time in the lines and we get answers to our health questions.

"When we get support from our work places to honor our appointment dates and also employer support like sick leave and promotions".

\section{Discussion}

\subsection{Demographic Characteristics in Relation to Satisfaction with Life}

Out of the total number of participants, the highest proportion $242 / 353(68.6 \%)$ of respondents were in the age group of 50 - 59 years, with more than half 198/353 (56.1\%) of the respondents being female. The high number of female respondents could be explained by the good seeking behavior of females in comparison to males. Also, the fact that across the sub-Saharan African region, gender-related norms all too often grant men the power to initiate and dictate the terms of sex, making it extremely difficult for women to protect themselves 
from either HIV or any other sexually transmitted diseases [24].

In terms of employment, the highest proportion of respondents $216 / 353$ (61.2\%) was employed. This could be explained by the fact that the clinic is in the capital city of Kampala were most people are employed or run so many forms of business.

\subsection{Responses to Illness Related Discrimination and Impact on Satisfaction with Life}

All the significant reasons to satisfaction with life at a multivariate analysis came from responses to illness related discrimination.

In this study, revealed that $70 \%$ of Clients who were seen before others were satisfied with life compared to those $26 \%$ who were not seen before even when they arrived early at the clinic. This had a significant association to satisfaction with life even at a multivariate analysis, were patients who disagreed others are seen before you when you are first to arrive, had an odds ratio of 2.87 compared to agreeing, which can be explained by the fact that since they are elderly patients they do not want to stay for long hours in the clinic and in the clinic mostly all were seen on time if they arrived early and this has an impact on their satisfaction.

In this current study during the focus group discussion, the participants noted on the effect of waiting for long in the clinic which affects their satisfaction with life.

$5.7 \%$ agreed that health care workers think they are bad patients probably that they are responsible for their illness and this could impact their satisfaction odds, $63.5 \%$ disagreed and believed that health care workers think of them as good patients and this could positively impact their levels of satisfaction. This is so because patients psychologically heal by the way health workers relate with them and that can only be achieved in enhancing good communication skills. This was in line with a similar study [25] conducted in Tanzania.

Therefore, it is recommended that health workers should have continuous trainings on how to improve their communication skills especially with clients since it is evident that it increases patient satisfaction.

$4 \%$ of the respondents in this study agreed that a family member would not share with them room or clothes because of their status. This was different from the 2002 survey which indicated that $80.8 \%$ of participants would not sleep in the same room as someone who was HIV positive, while $94.5 \%$ would not talk to someone who was HIV positive [26]. In comparison, data from the 2005 survey indicated that less than half of participants (46.5\%) indicated hesitance about marrying someone with HIV/AIDS, while $46.8 \%$ said they would have a problem having protected sex with a partner who has HIV/AIDS [26].

Such studies where not far from defining our study which at multivariate analysis, not being sure whether friend or family member cannot share room/ utensil/clothes with you reduced the odds of being satisfied by $95 \%$ when compared to agreeing and this probably also could later lead to patients not disclos- 
ing their status because of fear to be discriminated.

In this study, at a multivariate analysis disagreeing that friend or family member blames you for not getting better was significant with an odds ratio of 5.65 compared to agreeing. This meant that most patients were satisfied that their family member would not blame them for their not getting better, hence would expect support from a family member in regard to their illness.

Also disagreeing that your employer can never promote you had an odds ratio of 6.87 compared to agreeing at multi variate analysis. This meant that majority of the employed patients believe they can get in better positions at their workplace and were supported through promotions at work irrespective of their status. This improved their satisfaction with life. This was different from other studies in south Africa that shown that one in five of people living with HIV have lost a job or place to stay because of their positive HIV status whereas more than a third reported to have had internal feelings of shame or guilt because of their status [27].

\subsection{Responses to Barriers of Health Care and Social Services and Effect to Satisfaction with Life}

50.4\% respondents agreed that public knowledge to HIV is inadequate at univariate analysis. A lack of skills, lack of education and limited access to resources play a significant role in how people cope with HIV/AIDS hence affects their satisfaction with life. This therefore means that patients need as much information as possible about HIV so as to cope with the infection and this in the end gives them satisfaction with life through control of disease.

There was no significant association between worried to stigmatization with satisfaction with life among respondents in this study. This was similar to studies in south Africa which showed that one in five of people living with HIV have lost a job or place to stay because of their positive HIV status whereas more than a third reported to have had internal feelings of shame or guilt because of their status [27]. The sensed stigma or anticipated discrimination has a great influence on people with HIV/AIDS [28]. Disclosure of one's seropositivity causes more anxiety than only fear and uncertainty of other people's reaction [29]. In this study, patients disagreed to not being recognized for activities and socializing in the society with odds of 3.07 and 0.52 at bivariate analysis respectively. However, the odds of uncertainty or not sure of disclosing to family members was 2.53 compared to agreeing, probably for fear of discrimination or stigmatization. The more respondents worry about stigmatization by the community and family, the more their odds of satisfaction with life reduce.

In this study, patients that participated in the focus group discussion also noted that if community does not involve elderly HIV patients in community activities, it has statistical significance with their satisfaction with life. When asked about when do they know they are satisfied with life they responded;

"When we have access to social services and support in our communities and from our family members". However, this differs to other studies done, the el- 
derly may refrain from social interaction due to fear of stigmatization, leaving them isolated and reducing their quality of life [30]. Other studies show that generally elderly people who are actively involved in society, have positive moods and attitudes, positive emotions and relationships with friends and family; have a less physical and health complications and are more likely to live longer [31].

The effect that the clinic setting has on adherence should not be underestimated. This study at bivariate analysis shows that the odds of not being sure about being seen visiting the clinic were 2.17 compared to agreeing. This be due to so many characteristics, clinic characteristics that impact on adherence and satisfaction include; proximity to the patient's home or place of work, the expense of getting there, lengthy delays between appointments, clinic opening and closing times, long waiting times, lack of services such as childcare, privacy, confidentiality, and unsympathetic or inconsiderate staff [32] [33].

\subsection{Responses to Physical Well-Being, Social Support and Coping and Its Effect on Satisfaction with Life}

Help from others to adhere in this study had a significant association with satisfaction with life at a bivariate level of analysis. The position of personally helping themselves to adhere to the medication had 63.12 odds of satisfaction compared to a friend/relative. This meant that the elderly HIV patients want to solve their own issues and do not need help from others to adhere to their drugs as this will predispose them to disclosing hence reducing the level of their satisfaction with life. This was different compared to other previous studies done, where the elderly affected by and with HIV/AIDS tend to decrease their participation in social activities because they are fearful of possible stigmatization [34].

The stigmatization is perpetuated by negative stereotypes such as irrational fear of transmission through engagement with these caregivers, or even the notion that people with HIV/AIDS are sexually promiscuous. Other research in parallel with this study has found that the elderly finds comfort, assurance and hope in social settings [35] [36]. Social support is a predictor of increased quality of life, which can be found in participation in social activities such as religion [37]. Poor social support is one of the significant factors related with psychological problems in HIV/AIDS [38].

Other studies show that social support decreases signs and symptoms of disease and increase the quality of life of HIV patients [39]. Increasing social support increases the quality of life of HIV/AIDS persons [40]. Social support is significant predictor of quality of life [41] [42] [43]. It is significantly associated with better quality of life, minimizes the depressive symptoms among HIV/AIDS patients [44].

\section{Conclusions}

Elderly HIV patient satisfaction with life needs to be addressed holistically if we 
are to contribute to retention in care of this group of patients and prolong their life. Statistically significant variable was illness related to discrimination that produced all significant reasons.

Patients who were seen before others especially when they came early at the clinic were more satisfied with life, compared to those that were not seen before others. This therefore calls for delivery care models that can target the elderly in an HIV setting and possibly contribute to good retention in care. In addition to this, patients considered satisfaction when there was good communication ethics demonstrated by the health care workers who treated them well and not to label them as bad patients.

The Mulago HIV clinic and other clinics dealing with HIV care of elderly patients need to create more time or segregate service delivery models to ensure the elderly can also be handled in unique ways similar to adolescent HIV clinics so that they can receive services with ample time and quicker.

Regarding the promotions at workplaces, it was clear that the support given to these patients at workplaces is key to increasing their satisfaction with life and needs to be addressed such that equal opportunities are provided to the employees irrespective of their status.

HIV care centers should also emphasize more on sensitizing the public through awareness programs that these elderly patients need equal opportunities and support at workplaces and in community activities

Also, to note is that, the share of the rooms/utensils and clothes with HIV elderly patients contributes to satisfaction with life and $95 \%$ were not sure if a family member would share with them, probably because they would fear for stigmatization. This therefore calls for family support to the elderly and not to discriminate them or even fail to socialize with them.

Furthermore, regarding the need for support from family or friend and not putting blame is key to creating satisfaction with life; HIV elderly patients were more satisfied with life if they did not get blamed for not getting better by family or friend, meaning that most of these elderly HIV patients want support to comfort them rather than put blames on them by their family or even friends.

Counselling services targeting care takers of HIV elderly patients need to be strengthened and not rather just take it for granted that these are adults and they can easily handle their health but rather be targeted to address issues of stigmatization and socio copping in a friendly way. There has to be a strategy through use of more HIV counselling efforts by the health care workers to ensure the care takers of the HIV elderly patients understand the advantages of social support they have to offer.

The government needs to set up more HIV clinics in government health care facilities closer to the people, equip them with staff and drugs but also put emphasis on HIV elderly care.

Further research should be done directly towards HIV elderly patients because they suffer several challenges which need to be addressed. 


\section{Authors' Contribution}

Francis Kalule: Conceptualization, methodology, investigation, data curation, formal analysis, writing-original draft, writing-review and editing. Alimah Kyomuhangi: Conceptualization, methodology, investigation, writing-original draft, writing-review and editing. Micheal Buwembo: Methodology, formal analysis, writing—original draft, writing—review and editing. Thomas Katairo: Methodology, formal analysis, writing-original draft, writing-review and editing. Martha Tusabe: Methodology, formal analysis, writing-original draft, writing—review and editing

\section{Conflicts of Interest}

The authors declare no conflicts of interest regarding the publication of this paper.

\section{References}

[1] Centers for Disease Control and Prevention (2014) HIV Surveillance Report. Vol. 26.

[2] Schoenfelder, T., Klewer, J. and Kugler, J. (2011) Determinants of Patient Satisfaction: A Study among 39 Hospitals in an In-Patient Setting in Germany. International Journal for Quality in Health Care, 23, 503-509. https://doi.org/10.1093/intqhc/mzr038

[3] Jenkinson, C., Coulter, A., Bruster, S., Richards, N. and Chandola, T. (2002) Patients' Experiences and Satisfaction with Health Care: Results of a Questionnaire Study of Specific Aspects of Care. Quality \& Safety in Health Care, 11, 335-339. https://doi.org/10.1136/qhc.11.4.335

[4] Yellen, E., Davis, G. and Ricard, R. (2002) The Measuring of Patient Satisfaction. Journal of Nursing Care Quality, 16, 23-29. https://doi.org/10.1097/00001786-200207000-00005

[5] Myburgh, N.G., Solanki, G.C., Smith, M.J. and Lalloo, R. (2005) Patient Satisfaction with Health Care Providers in South Africa: The Influences of Race and Socioeconomic Status. International Journal for Quality in Health Care, 17, 473-477. https://doi.org/10.1093/intqhc/mzi062

[6] Kagashe, G.A. and Rwebangila, F. (2011) Patient Satisfaction with Health Care Services Provided at HIV Clinics at Amana and Muhimbili Hospitals in Dar es Salaam. African Health Sciences, 11, S60-S66. https://doi.org/10.4314/ahs.v11i3.70072

[7] Crane, H.M., Lober, W., Webster, E., Harrington, R.D., Crane, P.K., Davis, T.E. and Kitahata, M.M. (2007) Routine Collection of Patient-Reported Outcomes in an HIV Clinic Setting: The First 100 Patients. Current HIV Research, 5, 109-118. https://doi.org/10.2174/157016207779316369

[8] UNAIDS (2014) Joint United Nations Programme on HIV/AIDS, 2014. The Gap Report. Geneva.

[9] Muhondwa, E.P., Leshabari, M.T., Mwangu, M., Mbembati, N. and Ezekiel, M.J. (2008) Patient Satisfaction at the Muhimbili National Hospital in Dar es Salaam, Tanzania. East African Journal of Public Health, 5, 67-73. https://doi.org/10.4314/eajph.v5i1.38974

[10] Bajunirwe, F., Tumwebaze, F., Akakimpa, D., Kityo, C., Mugyenyi, P. and Abongo- 
mera, G. (2018) Towards 90-90-90 Target: Factors Influencing Availability, Access, and Utilization of HIV Services-A Qualitative Study in 19 Ugandan Districts. BioMed Research International, 2018, Article ID: 9619684. https://doi.org/10.1155/2018/9619684

[11] Ministry of Health, Uganda (2019) Uganda Population-Based HIV Impact Assessment (UPHIA) 2016-2017: Final Report. Ministry of Health, Kampala.

[12] Cahill, S. and Valadéz, R. (2013) Growing Older with HIV/AIDS: New Public Health Challenges. American Journal of Public Health, 103, e7-e15. https://doi.org/10.2105/AJPH.2012.301161

[13] Youssef, E., Wright, J., Delpech, V., et al. (2018) Factors Associated with Testing for HIV in People Aged $\geq 50$ Years: A Qualitative Study. BMC Public Health, 18, 1204. https://doi.org/10.1186/s12889-018-6118-x

[14] World Health Organization (2002) Innovative Care for Chronic Conditions: Building Blocks for Actions: Global Report.

[15] Epping-Jordan, J.E., Pruitt, S.D., Bengoa, R. and Wagner, E.H. (2004) Improving the Quality of Health Care for Chronic Conditions. Quality \& Safety in Health Care, 13, 299-305. https://doi.org/10.1136/qshc.2004.010744

[16] Nuño, R., Coleman, K., Bengoa, R. and Sauto, R. (2012) Integrated Care for Chronic Conditions: The Contribution of the ICCC Framework. Health Policy, 105, 55-64. https://doi.org/10.1016/j.healthpol.2011.10.006

[17] Narayan, C.S., Sharmistha, B. and Abdur, R.M. (2016) A Cross-Sectional Study on Patient Satisfaction in an Urban Health Care Centre of Siliguri Municipal Corporation, Darjeeling, West Bengal. Medical Journal of Dr. D.Y. Patil University, 9, 325 330. https://doi.org/10.4103/0975-2870.182502

[18] Martin, L.R., Williams, S.L., Haskard, K.B. and Dimatteo, M.R. (2005) The Challenge of Patient Adherence. Therapeutics and Clinical Risk Management, 1, 189199.

[19] Patton, M.Q. (1990) Qualitative Evaluation and Research Methods. 2nd Edition, Sage Publications, Inc., London.

[20] Slovin, E. (1960) Slovin's Formula for Sampling Technique. https://prudencexd.weebly.com

[21] Pavot, W. and Diener, E. (2008) The Satisfaction with Life Scale and the Emerging Construct of Life Satisfaction. The Journal of Positive Psychology, 3, 137-152. https://doi.org/10.1080/17439760701756946

[22] Diener, E., Emmons, R.A., Larsen, R.J. and Griffin, S. (1985) The Satisfaction with Life Scale. Journal of Personality Assessment, 49, 71-75.

https://doi.org/10.1207/s15327752jpa4901 13

[23] Angell, M. (1997) The Ethics of Clinical Research in the Third World. The New England Journal of Medicine, 337, 847-849. https://doi.org/10.1056/NEJM199709183371209

[24] Lekalakala-Mokegele, E. (2016) Exploring Gender Perceptions of Risk of HIV Infection and Related Behavior among Elderly Men and Women of Ga-Rankuwa, Gauteng Province, South Africa. SAHARA J: Journal of Social Aspects of HIVIAIDS Research Alliance, 13, 88-95. https://doi.org/10.1080/17290376.2016.1218790

[25] Khamis, K. and Njau, B. (2014) Patients' Level of Satisfaction on Quality of Health Care at Mwananyamala Hospital in Dar es Salaam, Tanzania. BMC Health Services Research, 14, 400. https://doi.org/10.1186/1472-6963-14-400

[26] Shisana, O., Rehle, T., Simbayi, L.C. and Parker, W. (2005) South African National 
HIV Prevalence, HIV Incidence, Behavior and Communication Survey. Human Sciences Research Council, Cape Town.

[27] Shisana, O. and Simbayi, L.C. (2007) South African National HIV Prevalence, HIV Incidence, Behavior and Communication Survey. Technical Report, Human Sciences Research Council, Cape Town.

[28] Ochako, R., Ulwodi, D., Njagi, P., et al. (2011) Trends and Determinants of Comprehensive HIV and AIDS Knowledge among Urban Young Women in Kenya. AIDS Research and Therapy, 8, 11. https://doi.org/10.1186/1472-6963-14-400

[29] Wright, K., Naar-King, S., Lam, P., Templin, T. and Frey, M. (2007) Stigma Scale Revised: Reliability and Validity of a Brief Measure of Stigma for HIV+ Youth. Journal of Adolescent Health, 40, 96-98. https://doi.org/10.1016/j.jadohealth.2006.08.001

[30] Lekalakala-Mokegele, E. (2011) A Literature Review of the Impact of HIV and AIDS on the Role of the Elderly in the Sub-Saharan African Community. Health SA Gesondheid, 16, 564-570. https://doi.org/10.4102/hsag.v16i1.564

[31] Diener, E. and Chan, M.Y. (2011) Happy People Live Longer: Subjective Wellbeing Contributes to Health and Longevity. Applied Psychology: Health and Well-Being, 3, 1-43. https://doi.org/10.1111/j.1758-0854.2010.01045.x

[32] Syed, S.T., Gerber, B.S. and Sharp, L.K. (2013) Traveling towards Disease: Transportation Barriers to Health Care Access. Journal of Community Health, 38, 976993. https://doi.org/10.1007/s10900-013-9681-1

[33] Marbouh, D., Khaleel, I., Al Shanqiti, K., Al Tamimi, M., Simsekler, M., Ellahham, S., Alibazoglu, D. and Alibazoglu, H. (2020) Evaluating the Impact of Patient NoShows on Service Quality. Risk management and Healthcare Policy, 13, 509-517. https://doi.org/10.2147/RMHP.S232114

[34] Alpaslan, A. and Mabutho, S.L. (2005) Caring for AIDS Orphans: The Experiences of Elderly Grandmother Caregivers and AIDS Orphans. Social Work, 41, 276-295.

[35] Kemperman, A., van den Berg, P., Weijs-Perrée, M. and Uijtdewillegen, K. (2019) Loneliness of Older Adults: Social Network and the Living Environment. International Journal of Environmental Research and Public Health, 16, 406. https://doi.org/10.3390/ijerph16030406

[36] Ramocha, L.M., Louw, Q.A. and Tshabalala, M.D. (2017) Quality of Life and Physical Activity among Older Adults Living in Institutions Compared to the Community. The South African Journal of Physiotherapy, 73, 342. https://doi.org/10.4102/sajp.v73i1.342

[37] Park, J., Roh, S. and Yeo, Y. (2011) Religiosity, Social Support, and Life Satisfaction among Elderly Korean Immigrants. The Gerontologist, 52, 641-649. https://doi.org/10.1093/geront/gnr103

[38] Adewuya, A.O., Afolabi, M.O., Ola, B.A., Ogundele, O.A., Ajibare, A.O. and Oladipo, B.F. (2007) Psychiatric Disorders among the HIV-Positive Population in Nigeria: A Control Study. Journal of Psychosomatic Research, 63, 203-206. https://doi.org/10.1016/j.jpsychores.2007.03.006

[39] Hough, E.S., Magnan, M.A., Templin, T. and Gadelrab, H.F. (2005) Social Network Structure and Social Support in HIV-Positive Inner-City Mothers. Journal of the Association of Nurses in AIDS Care, 16, 14-24.

https://doi.org/10.1016/j.jana.2005.05.002

[40] Charkhian, A., Fekrazad, H., Sajadi, H., Rahgozar, M., Haji Abdolbaghi, M. and Maddahi, S. (2014) Relationship between Health-Related Quality of Life and Social Support in HIV-Infected People in Tehran, Iran. Iranian Journal of Public Health, 43, 100-106. 
[41] Ewa, G. and Marcin, R. (2019) Trajectories of Health-Related Quality of Life and Perceived Social Support among People Living with HIV Undergoing Antiretroviral Treatment: Does Gender Matter? Frontiers in Psychology, 10, 1664.

https://www.frontiersin.org/article/10.3389/fpsyg.2019.01664 https://doi.org/10.3389/fpsyg.2019.01664

[42] Huang, Y., Luo, D., Chen, X., Zhang, D., Huang, Z. and Xiao, S. (2019) Role of Psychosocial Status in Predicting Health-Related Quality of Life at 1-Year FollowUp among Newly Diagnosed People Living with HIV. PLOS ONE, 14, e0224322. https://doi.org/10.1371/journal.pone.0224322

[43] Garrido-Hernansaiz, H., Heylen, E., Bharat, S., et al. (2016) Stigmas, Symptom Severity and Perceived Social Support Predict Quality of Life for PLHIV in Urban Indian Context. Health and Quality of Life Outcomes, 14, 152. https://doi.org/10.1186/s12955-016-0556-x

[44] Sikkema, K.J., Dennis, A.C., Watt, M.H., Choi, K.W., Yemeke, T.T. and Joska, J.A. (2015) Improving Mental Health among People Living with HIV: A Review of Intervention Trials in Low- and Middle-Income Countries. Global Mental Health (Cambridge, England), 2, e19. https://doi.org/10.1017/gmh.2015.17 